\section{Prof. Jane Ann Plant}

\section{IUGS Councilor}

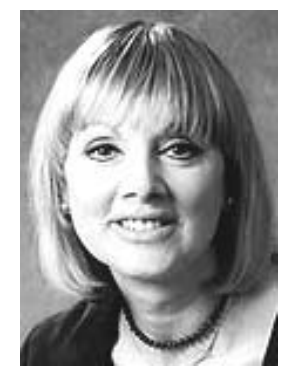

Professor Plant achieved a First Class Honours Degree in Geology with Special Geochemistry from the University of Liverpool in 1967 and was awarded the Liverpool and Manchester Geological Society Prize as the most outstanding student of her year. She was immediately appointed as a Scientific Officer at the British Geological Survey (BGS) where her main responsibility was for the development of methods for systematic high-resolution geochemical mapping of the UK and subsequently conduct of the programme.

While undertaking this work, and then progressing from Senior Scientific Officer to Principal Scientific Officer within the BGS, she completed a $\mathrm{PhD}$ in geochemistry at the University of Leicester. She was awarded the Consolidated Gold Fields Premium Award for her first paper published in the Transactions of the Institution of Mining and Metallurgy, entitled "Orientation studies on stream sediment sampling for a regional geochemical survey in northern Scotland."

In 1983, she was promoted to an Individual Merit Senior Principal Scientific Officer on the basis of her scientific contribution, and led many research programmes concerned with the relationship between geochemistry, crustal evolution and ore deposits. In the late 1980s she took a sabbatical from the BGS to work with industry in North America, where she was Vice President of Middleton Exploration, involved with gold and other metalliferous mineral exploration programmes. On her return to the UK she was appointed Head of the Applied Geochemistry Group at the BGS.

Her responsibilities by now had widened considerably and they included economic geology and environmental geochemistry, nationally and internationally. In 1991, she was promoted to Assistant Director of the BGS with responsibility not only for minerals and geochemistry, but also fluid processes and waste management research. In 2000, Jane was promoted to Chief Scientist of the BGS and Head of the Geoscience Resources and Facilities Directorate with responsibility for the maintenance and development of scientific capability and expertise.

Her interest in geochemistry remains and she is now joint leader with Dr David Smith of the United States Geological Survey of the International Union of Geological Sciences/International Association of Geochemistry and Cosmochemistry, Global Geochemical Baselines programme which aims to produce a geochemical map of the world! The aim is to use geochemistry strategically to identify, predict and mitigate problems caused by chemicals in the environment such as those caused by arsenic or fluoride, as well as identifying areas with deficiencies in essential trace elements such as selenium or iodine. China was the first country to complete its database and Europe has almost completed its first continental geochemical baseline.

As a student, Jane won the Murchison Prize of the Geological Society of London and in recent years she has been awarded Honorary Doctorate from the Open University and the University of Exeter for her contribution to Earth Sciences and for academic and scholarly distinction. In 1997, she was awarded the CBE for services to earth sciences and the Lord Lloyd of Kilgerran Prize for Science and Technology, and in 1999 she was appointed to the Worshipful Company of Water Conservators and was made a Freeman of the City of London.
Jane has taken on numerous external appointments and temporary posts during her career. She is presently a member of the Royal Commission on Environmental Pollution; she is a Visiting Professor at Liverpool University and a special Professor at Nottingham University. She has recently been appointed Professor of Geochemistry at Imperial College, London, and has taken over as Chairman of the Government's Advisory Committee on Hazardous Substances.

Jane is a member of a range of geological and geochemical learned societies and professional bodies. She is a Chartered Engineer as well as a Chartered Geologist, and she is also a Fellow of the Royal Society of Arts. In May this year, she was elected as the first woman President of the Institution of Mining \& Metallurgy.

She has lectured and published widely on economic geology, environmental geochemistry and sustainable development, and is the author of more than 200 peer reviewed publications and books. In 2000 she published an international best selling book called 'Your Life in Your Hands' about her successful battle against her own breast cancer which provides a great deal of advice for other sufferers of both breast and prostate cancer. This year she followed it up with a diet and lifestyle programme for healthy living entitled 'The Plant Programme' co-authored with fellow earth scientist, Gill Tidey.

Address:

Prof. Jane A. Plant

British Geological Survey

Keyworth

Nottingham NG12 5GG

UK

Tel: +44 1159363100

Fax: +441159363487

E-mail: jplant@bgs.ac.uk 